\title{
Role of Temperature and Growth Period in the Synthesis of Hydrothermally Grown $\mathrm{TiO}_{2}$ Nanorods
}

\author{
Ananthakumar Soosaimanickam¹,2,3,*, Pelin Yilmaz², Xuan Li , Joe Briscoe², Ann-Louise Anderson², \\ Steve Dunn², and Moorthy Babu Sridharan ${ }^{1}$ \\ ${ }^{1}$ Crystal Growth Centre, Anna University, Chennai 600 025, India \\ ${ }^{2}$ Material Research Institute, School of Engineering and Material Science (SEMS), Queen Mary University of London, \\ London E1 4NS, United Kingdom \\ ${ }^{3}$ Institute of Materials (ICMUV), University of Valencia, Spain
}

\begin{abstract}
Highly uniformed, surfactant free and vertically oriented titanium-di-oxide $\left(\mathrm{TiO}_{2}\right)$ nanorods were grown on pre-treated fluorine doped tin oxide (FTO) using hydrothermal method through titanium tetra butoxide $\left(\mathrm{Ti}(\mathrm{OBu})_{4}\right)$ as titanium source. Three different temperatures $130{ }^{\circ} \mathrm{C}, 150{ }^{\circ} \mathrm{C}$ and $180{ }^{\circ} \mathrm{C}$ were followed to grow the nanorods at a fixed reaction time of $4 \mathrm{~h}$. The prepared $\mathrm{TiO}_{2}$ nanorods were annealed at the temperatures of $550{ }^{\circ} \mathrm{C}$ and $600{ }^{\circ} \mathrm{C}$ for $3 \mathrm{~h}$. X-ray diffraction (XRD) analysis shows that obtained nanorods exhibit pure rutile phase. From scanning electron microscopy (SEM) analysis, it was found that increasing temperature leald to decreasing the diameter of the nanorods. In addition to these, formation of hierarchical type $\mathrm{TiO}_{2}$ nanorods were also observed at $130{ }^{\circ} \mathrm{C}$. UV-visible spectra analysis was carried out to find the influence ${ }_{\lambda}$ diameter of the nanorods on its optical properties. The plausible mechanism of the growth process was also discussed.
\end{abstract}

Keywords: Titanium-di-oxide, Solar Cells, Hydrothermal Synthesis, Nanorods, Rutile Phase,

\section{INTRODUCTION}

Semiconductor nanomaterials based flexible, cost-effective devices fabricated by solution-processed methods is the current area of research interest in order to overcome the future energy crisis. In this regard, synthesis of semiconductor nanomaterials with different dimensions is one of the the most triggered area of research. This is because of the fascinating structural and optical properties of the semiconductor nanomaterials in solution as well as in thin film. Titanium-diłoxide $\left(\mathrm{TiO}_{2}\right)$, a wide-bandgap semiconductor $\left(E_{g}=3.2 \mathrm{eV}\right)$ is concentrdmuch for the application of future generation solar cells like dye-sensitized solar cells (DSSCs), quantum-dot sensitized solar cells (QDSSCs) and perovskite solar cells [1, 2]. Hybrids of $\mathrm{TiO}_{2}$ nanoparticles and semiconducting polymer for the construction of bulk-heterojunction type of hybrid solar cells in which $\mathrm{TiO}_{2}$ nanoparticles are effectively functioning as the electron acceptor [3-6]. Moreover, $\mathrm{TiO}_{2}$ nanomaterials have also proved as potential candidates for the photocatalysis, photoelectrochemical water splitting,

*Author to whom correspondence should be addressed. sensors and lithium batteries [7-9]. For the solar cell applications, a thin layer of commercially obtained $\mathrm{TiO}_{2}$ powder (or) sol-gel prepared $\mathrm{TiO}_{2}$ nanoparticles is deposited on a conducting substrate, typically on a Fluorine doped tin oxide (FTO). A mesoporous structure of $\mathrm{TiO}_{2}$ is normally used to harvest large amount of photons in DSSC device. Due to the enhanced carrier transport, low recombination rate and high surface area, one dimensional (1D) $\mathrm{TiO}_{2}$ nanostructures such as nanowires, nanorods (NRs) and nanotubes are considered more beneficial for these kind of applications [10-13]. Therefore, synthesis of 1D $\mathrm{TiO}_{2}$ nanostructures through simple, cost-effective methods is being preferred. When synthesizing $1 \mathrm{D} \mathrm{TiO}_{2}$ nanostructures using wet chemical methods in presence of long chain capping ligands, removal of these insulating ligands is a tedious process and a programmed post-treatment is often carried out before applying the nanoparticles for the fabrication of potential devices. This is a time-consuming process and also possibility of aggregation in solution is dominated. Thus, surfactant-free synthesis of $1 \mathrm{D} \mathrm{TiO}_{2}$ nanostructures is indeed much useful for the direct application of the fabrication of optoelectronic devices. In the 
synthesis of $\mathrm{TiO}_{2}$ nanoparticles, sol-gel method based hydrolysis of alkoxide precursor is generally carried out in the presence of ${ }_{\wedge}^{a_{\text {strong }}}$ acid or base [14-17]. Considering the synthesis of $\mathrm{TiO}_{2} \mathrm{NRs}$, hydrothermal synthesis is the most often used method in order to synthesise 垃作 well aligned NRs with optimized dimensions [18-20]. Also, to carry out synthesis through hydrothermal method, very simple precursors and experimental arrangement are required. Among the three phases that exist in $\mathrm{TiO}_{2}$, rutile phase is exhibiting with improved light scattering properties, high refractive index and very good photocatalytic properties. Thus, synthesis of $\mathrm{TiO}_{2}$ NRs, with rutile phase through hydrothermal method is attract mueh-in order to utilize it for energy related applications. Apart from the synthesis, the length and diameter of the synthesized NRs could be precisely tuned through controlling the physical parameters such as temperature, reaction time and ratio of the precursors. The first report by Liu and Aydil had opened a pathway in the growth of vertically aligned $\mathrm{TiO}_{2}$ NRs for solar cells and photocatalytic applications [21]. After this, many experimental efforts were undertaken to grow the $\mathrm{TiO}_{2} \mathrm{NRs}$ on a conducting substrate and considerable success was achieved in terms of device efficiency. For instance, Mali et al have achieved over $7 \%$ efficiency using hydrothermally synthesized $\mathrm{TiO}_{2}$ NRs having dendritic hollow urchin like morphology [22]. Similarly, a three dimensional (3D) hierarchical rutile nanostructures gave an impressive $8.6 \%$ efficiency with a metal-free organic sensitizer [23]. In addition to these, further decoration of $\mathrm{TiO}_{2} \mathrm{NRs}$ by other semiconductor nanostructures was found to be enhancing the efficiency still higher [24]. Despite these experimental results, a clear analysis of influence of physical paramaters on the hydrothermal synthesis of $\mathrm{TiO}_{2} \mathrm{NRs}$ is required. Here, the present work is focussed on the synthesis of $\mathrm{TiO}_{2}$ NRs with different diameter and length through hydrothermal method at different time intervals. By carefully tuning the physical parameters, we observe that charge-transport of the annealed films would be largely dependent on the morphology change attributed with the synthesized $\mathrm{TiO}_{2}$ NRs. Critical analysis of influence of temperature on the growth of NRs is much needed in order to explore its role on the crystallinity and charge transport. In this work, the synthesized NRs were annealed at different temperatures and at different time intervals. The structural, optical and morphological changes on the synthesized $\mathrm{TiO}_{2}$ NRs under the influence of reaction temperature and annealing temperature are addressed in detail.

\section{EXPERIMENTAL METHODS}

\subsection{Materials}

Fluorine doped tin oxide, FTO $\left(\mathrm{SnO}_{2}: \mathrm{F}\right)$, hydrochloric acid $(\mathrm{HCl})$, titanium $(\mathrm{IV})$ butoxide $\left(\mathrm{Ti}(\mathrm{OBu})_{4}\right)$ obtained from Sigma Aldrich were used for the experiments.

\subsection{Synthesis of $\mathrm{TiO}_{2} \mathrm{NRs}$ by hydrothermal method}

At first, the FTO coated glass slides were pretreated using acetone and isoproponal for $15 \mathrm{~min}$ and rinsed using deionized water to clean the organic residues from the surface. Meanwhile, the precursor solution was prepared using $[6 \mathrm{M}$ of $90 \mathrm{ml}$ of dil. $\mathrm{HCl}]$ and $2.5 \mathrm{ml}$ of titanium (IV) butoxide and the mixture was allowed to stirrag for $30 \mathrm{~min}$ at room temperature. Then, this solution was transferred into a teflon lined autoclave and an FTO coated glass slide was kept inside the autoclave with FTO coated side facing towards downward. The autoclave was sealed tightly and kept in a hot oven for $4 \mathrm{hr}$. The reaction was carried out at three different temperatures $130{ }^{\circ} \mathrm{C}, 150{ }^{\circ} \mathrm{C}$, $180{ }^{\circ} \mathrm{C}$ respectively. After completion of the reaction, the FTO substrate was rinsed with deionized water and dried under nitrogen air. This substrate was further annealed at different temperaturesand different time periods in order to improve its crystallinity and to analyze the role of temperature on the morphology of the synthesized $\mathrm{TiO}_{2}$ NRs.

Absorption spectra were analyzed using a JASCO UVvisible conventional spectrophotometer in the range of 200-800 nm. SEM images were recorded using the Carl Zeiss MA15/EVO 18 Scanning Electron Microscope. In order to avoid the charging effect, gold/palladium alloy was coated on samples for SEM analysis. XRD patterns were taken using a powder X-ray diffractometer (SEI FERT) JSO DEBYEFLEX 2002 model with $\mathrm{CuK} \alpha 1(\lambda 1 / 40.154 \mathrm{~nm})$ radiation.

\section{RESULTS AND DISCUSSION}

The XRD patterns of the as synthesized $\mathrm{TiO}_{2}$ NRs at different temperatures and annealed $\mathrm{TiO}_{2} \mathrm{NRs}$ at different time periods are given in Figure 1. From the XRD patterns, the $2 \theta$ values $26.3,36.16,41.2,54.53,61.64$ are assigned with the (110), (101), (111), (211), and (220) crystal planes of the $\mathrm{TiO}_{2}$ [25]. All these peaks in the XRD patterns are indicating the presence of tetragonal rutile phase of $\mathrm{TiO}_{2}$ (JCPDS: 00001-0562). UV-visible spectra analysis of the synthesized $\mathrm{TiO}_{2}$ NRs at different temperatures is given in Figure 2. In the present work, three different temperatures, $130{ }^{\circ} \mathrm{C}, 150{ }^{\circ} \mathrm{C}$ and $180{ }^{\circ} \mathrm{C}$ were selected to carry out the experiment since through literature, we find that the morphology is greatly influenced in these temperatures. To find the influence of annealing time and growth time, the reaction time was kept as $4 \mathrm{~h}$. The UV-Visible spectra show the blue shift in the position of the absorption edge with increasing the temperature. This is because the $\mathrm{TiO}_{2}$ NRs growth is dependent on the temperature and increasing temperature result much thinner NRs which reflect its absorption. This morphology change is further analysed by scanning electron microscope (SEM) analysis and the SEM images of the as synthesized NRs at different temperatures are given in Figure 3. The results show that increasing temperature results reduction in the diameter of the $\mathrm{TiO}_{2}$ NRs due to the changes observed in the growth.

\section{Tis \\ dresit \\ mate serse}



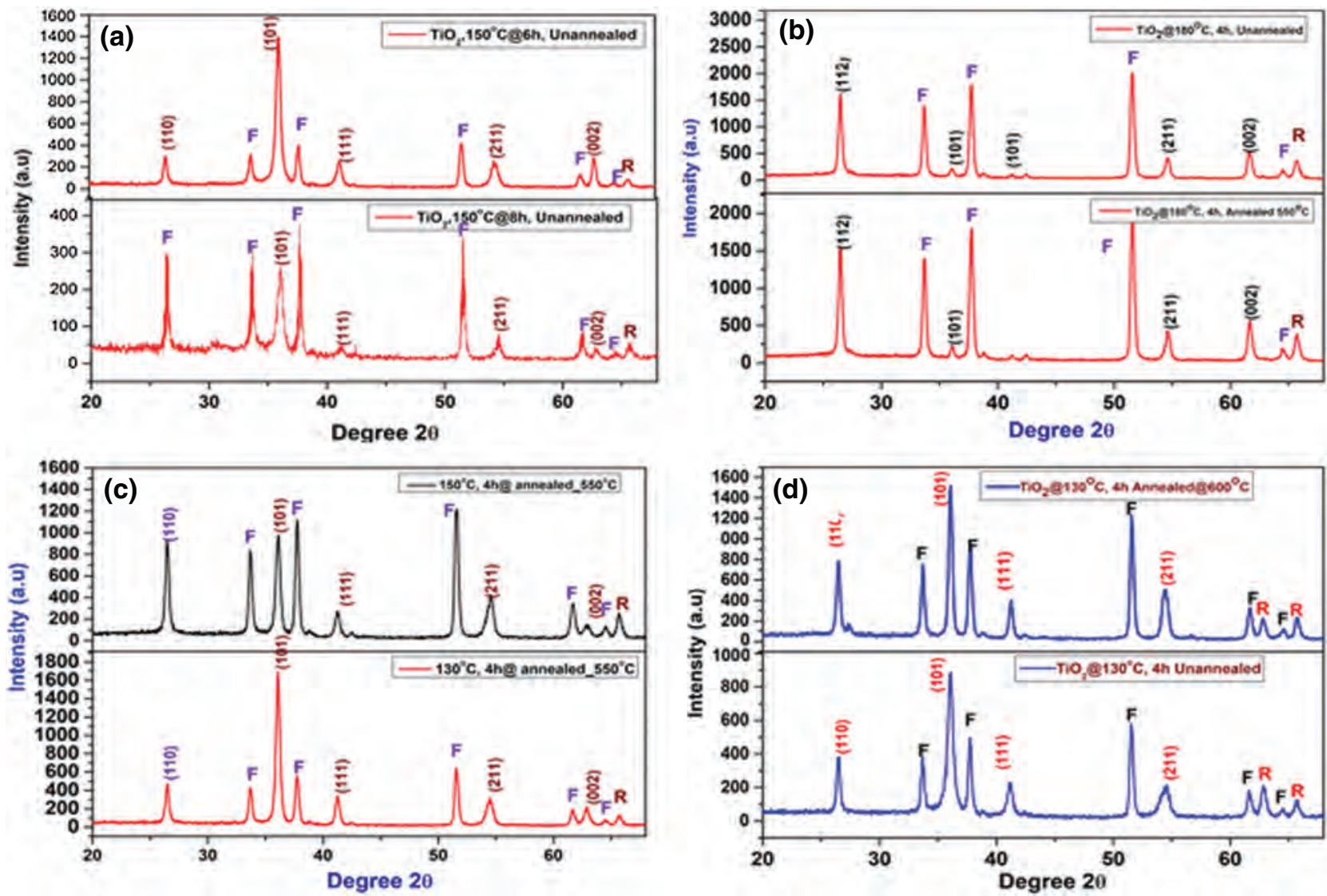

Figure 1. XRD patterns of the (a) Unannelead $\mathrm{TiO}_{2} \mathrm{NRs}$ grown at different reaction periods (b) annealed and unannealed $\mathrm{TiO}_{2} \mathrm{NRs}$ grown at $180{ }^{\circ} \mathrm{C}$ (b) different temperatures annealed at $550{ }^{\circ} \mathrm{C}$ (c) annealed $\mathrm{TiO}_{2}$ NRs synthesized at $150{ }^{\circ} \mathrm{C}$ and $130{ }^{\circ} \mathrm{C}$ (d) annealed and unannealed $\mathrm{TiO}_{2} \mathrm{NRs}$ grown at $130{ }^{\circ} \mathrm{C}(\mathrm{R}=$ rutile, $\mathrm{F}=\mathrm{FTO})$.

For the reaction temperature of $130{ }^{\circ} \mathrm{C}$, the formed $\mathrm{NRs}$ were possessed with larger diameter compared with NRs formed in other two temperatures (Fig. 3(a, b)). The diameter of the NRs observed in this case were around 130-170 $\mathrm{nm}$. Though the NRs are uniform, it can be seen that the

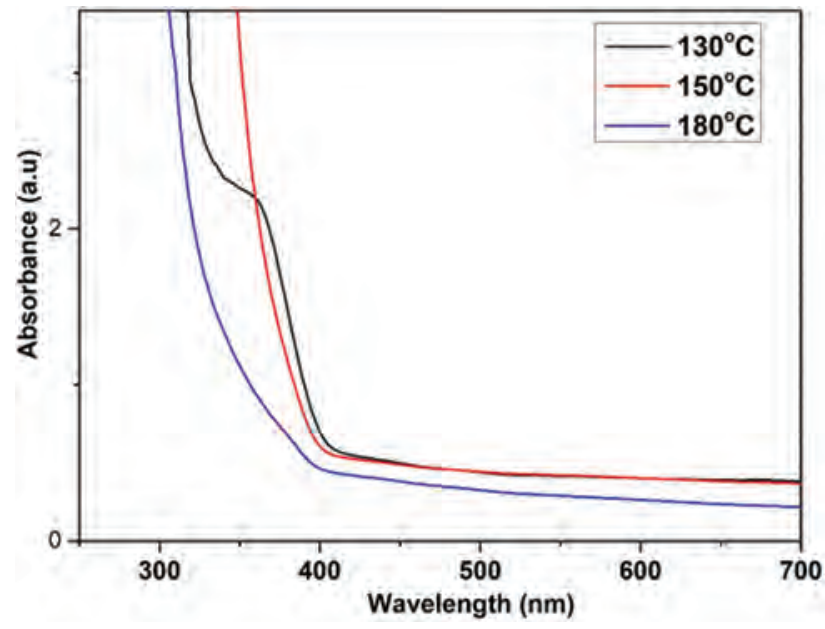

Figure 2. UV-visible spectra of the as-synthesized $\mathrm{TiO}_{2} \mathrm{NRs}$ grown at different temperatures.
NRs are started to assemble like a cluster in some places. For the growth temperature of $150{ }^{\circ} \mathrm{C}$, the diameter of the synthesized NRs was found to be about 100-120 (Figs. 3(c, d)). The cluster assembly behaviour was stilf higher in this case and this shows that the growth of the NRs can be correlated with the radial growth of the top $\mathrm{TiO}_{2}$ NRs layer with the bottom layer [26]. For the temperature of $180{ }^{\circ} \mathrm{C}$, it has been found that the shape of the NRs is observed as still thinner (Fig. 3(e, f)). These observations clearly confirm the significant influence of temperature on the diameter and growth pattern of the synthesized $\mathrm{TiO}_{2}$ NRs.

The as synthesized $\mathrm{TiO}_{2}$ NRs were further annealed in order to improve the crystallinity and also to find the role of annealing on the morphology of the NRs. To find the influence of annealing, two different temperatures over $550{ }^{\circ} \mathrm{C}$ and $600{ }^{\circ} \mathrm{C}$ at two different time periods The SEM images of annealed $\mathrm{TiO}_{2}$ NRs synthesized at different temperature under different time period is shown in Figure 4.

The results clearly reveal that annealing of $\mathrm{TiO}_{2}$ at different temperatures improves the crystallinity and also make variation in the diameter of the NRs. For example, when the $\mathrm{TiO}_{2} \mathrm{NRs}$ synthesized at $130{ }^{\circ} \mathrm{C}$ are annealed at $550{ }^{\circ} \mathrm{C} 3 \mathrm{~h}$ and $6 \mathrm{~h}$, the diameter of the NRs was 

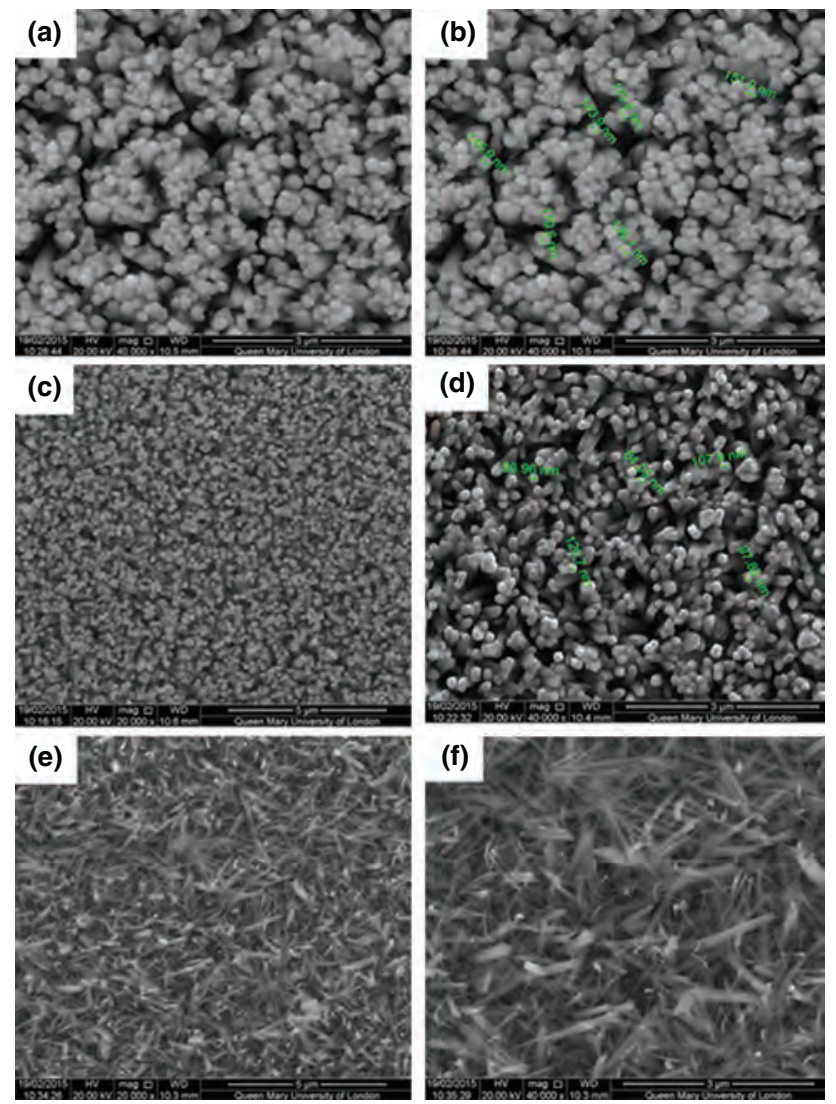

Figure 3. SEM images of the as synthesized $\mathrm{TiO}_{2} \mathrm{NRs}$ at $(\mathrm{a}, \mathrm{b}) 130{ }^{\circ} \mathrm{C}$ (c, d) $150{ }^{\circ} \mathrm{C}$ and $(\mathrm{e}, \mathrm{f}) 180{ }^{\circ} \mathrm{C}$. The reaction time duration in all these cases was maintained as $4 \mathrm{~h}$.

reduced from 120-200 $\mathrm{nm}$ to 75-120 $\mathrm{nm}$ (Fig 4(a, b)). Furthermore, it was found that formation of nanoflower like morphology was observed in the $\mathrm{TiO}_{2}$ NRs annealed at $550{ }^{\circ} \mathrm{C}$ for $3 \mathrm{~h}$. Formation of nanoflower morphology of $\mathrm{TiO}_{2}$ NRs under the influence of foreign ion, ionic liquids are already observed [27, 28]. In the present case, it is due to the increasing the annealing temperature and hence the significance of annealing in the formation of NRs through tuning the physical parameters has to be analysed in detail. Similarly, variations in the diameter were also observed for the $150{ }^{\circ} \mathrm{C}$ synthesized $\mathrm{TiO}_{2}$ NRs annealed at different temperatures (Fig 4(c, d)). For the NRs synthesized at $180{ }^{\circ} \mathrm{C}$, extremely thin shaped NRs were observed for the NRs annealed at $3 \mathrm{~h}$ and $6 \mathrm{~h}$ (Fig. 4(e, f)). It was also observed that these NRs are entirely different from the pristine $\mathrm{TiO}_{2}$ NRs synthesized at different temperatures. The schematic diagram of the change of morphology of the NRs at different temperatures is given in Figure 5. The clear mechanism of the formation of $\mathrm{TiO}_{2}$ NRs is described as follows. At initial stage, the alkoxide precursor (TBT) provide an atmosphere to generate the rutile nuclei on the surface of the substrate (FTO). During the reaction progress, the $\mathrm{Ti}^{3+}$ from TBT getting hydrolysed and formation of $\mathrm{TiOH}^{2+}$ takes place in solution. Because of the dissolved oxygen present in the water,
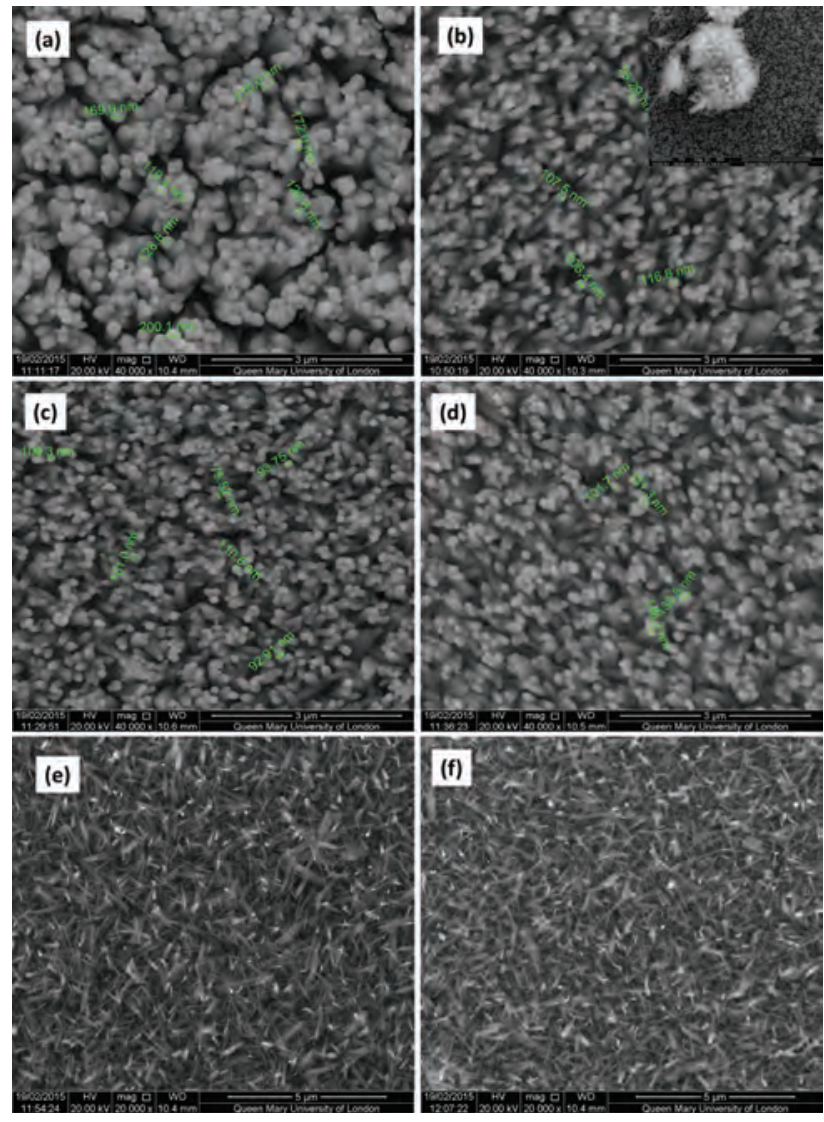

Figure 4. SEM images of the $\mathrm{TiO}_{2}$ NRs (a) synthesized at $130{ }^{\circ} \mathrm{C}$ annealed at $550{ }^{\circ} \mathrm{C}, 3 \mathrm{~h}$ (b) synthesized at $130{ }^{\circ} \mathrm{C}$ annealed at $600{ }^{\circ} \mathrm{C}$, $3 \mathrm{~h}$ and nanoflower morphology of $\mathrm{TiO}_{2}$ NRs (inset) (c) synthesized at $150{ }^{\circ} \mathrm{C}$ annealed at $550{ }^{\circ} \mathrm{C}, 3 \mathrm{~h}(\mathrm{~d})$ synthesized at $150{ }^{\circ} \mathrm{C}$ annealed at $600{ }^{\circ} \mathrm{C}, 3 \mathrm{~h}(\mathrm{e})$ synthesized at $180{ }^{\circ} \mathrm{C}$ annealed at $550^{\circ} \mathrm{C}, 3 \mathrm{~h}$ (f) synthesized at $180{ }^{\circ} \mathrm{C}$ annealed at $600{ }^{\circ} \mathrm{C}, 3 \mathrm{~h}$.

this $\mathrm{TiOH}^{2+}$ is oxidised and formation of Ti (IV) takes place. Through this $\mathrm{Ti}(\mathrm{IV})$ as the seed, growth of $\mathrm{TiO}_{2}$ NRs takes place in the solution. This formation of $\mathrm{TiO}_{2}$ initiated with the formation of $\mathrm{TiO}_{6}$ octahedra network and the growth of this octahedra network leading to extended chain like structure. Since growth of this structure takes place through [001] direction and through lowest surface energy plane $\{110\}$, formation of rutile structure is more favoured. Finally, a well oriented NRs array was obtained through the continuous supply of Ti(IV) nuclei from the solution. The presence of $\mathrm{HCl}$ prevents the continuous hydrolysis of the precursors and also encourage the growth

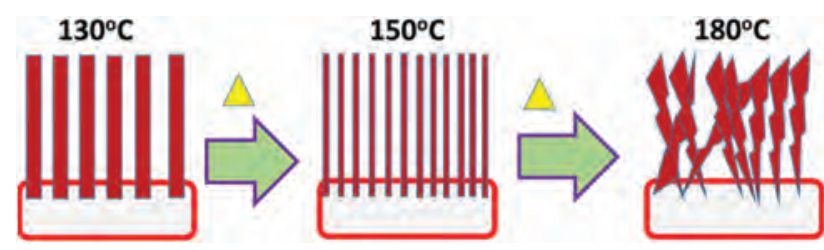

Figure 5. Schematic diagram of the formation of $\mathrm{TiO}_{2}$ NRs with different dimensions at different reaction temperatures. 
of NRs at [001] direction [9]. This significant influence of $\mathrm{HCl}$ on the growth of the $\mathrm{TiO}_{2}$ NRs also confirmed in previous observations [29-31]. Here, we followed three different temperatures $130{ }^{\circ} \mathrm{C}, 150{ }^{\circ} \mathrm{C}$ and $180{ }^{\circ} \mathrm{C}$. At the lower temperature ie, $130{ }^{\circ} \mathrm{C}$, the building block of the growth of $\mathrm{TiO}_{2}$ NRs is not disturbed by the temperature and growth facilitates without any disturbance. However, the individual NRs are not isolated in this case due to the growth pattern and when we annealed this film at higher temperature, because of this clustered growth, hierarchical nanoflower like structure was observed. This also continues at the temperature $150{ }^{\circ} \mathrm{C}$. However, compared with $130{ }^{\circ} \mathrm{C}$, the NRs grown at $150{ }^{\circ} \mathrm{C}$ are possessed less diameter but well isolated growth pattern of individual NRs. As the temperature continues, at higher temperatures, for example $180{ }^{\circ} \mathrm{C}$, because of the accelerated growth, the resultant NRs are appeared as the sheet like structures. It was observed in the present case the NRs formation takes place only when equal volume of water is used with the equal volume of the $\mathrm{HCl}$. Modulation of volume in both cases resulted absence of NRs formation on the substrate (FTO) which clearly represents the importance of volume of reactants on the growth of the NRs.

\section{CONCLUSIONS}

Synthesis of $\mathrm{TiO}_{2}$ NRs by hydrothermal method at different temperatures result NRs with different morphologies due to the influence of growth pattern with respect to temperatures. Synthesis of $\mathrm{TiO}_{2} \mathrm{NRs}$ using hydrothermal method provide a versatile approach to regulate the diameter as well as dimensions of the NRs. Further effort in utilizing these tunable nanostructures for photochemical conversion, photo catalysis applications through heteronanostructure configuration will lead a new avenue in terms of efficiency. Also, the carrier transport analysis of these structure will open other possible ways to explore their potential utilization for future devices.

Acknowledgments: Ananthakumar Soosaimanickam sincerely thanks Royal Society of Chemistry (RSC), United Kingdom for awarding 'Researcher Mobility Fellowship' to carry out the research work at SEMS, QMUL, London.

\section{References and Notes}

1. Chen, X. and Mao, S.S., 2007. Titanium dioxide nanomaterials: synthesis, properties, modifications, and applications. Chem. Rev., 107, pp.2891-2959.

2. Kojima, A., Teshima, K., Shirai, Y. and Miyasaka, T., 2009. Organometal halide perovskites as visible-light sensitizers for photovoltaic cells. J. Am. Chem. Soc., 131(17), pp.6050-6051.

3. Pei, J., Hao, Y.Z., Lv, H.J., Sun, B., Li, Y.P. and Guo, Z.M., 2016. Optimizing the performance of $\mathrm{TiO}_{2} / \mathrm{P} 3 \mathrm{HT}$ hybrid solar cell by effective interfacial modification. Chem. Phys. Lett., 644, pp.127-131.
4. Shen, L., Zhu, G., Guo, W., Tao, C., Zhang, X., Liu, C., Chen, W., Ruan, S. and Zhong, Z., 2008. Performance improvement of $\mathrm{TiO}_{2} / \mathrm{P} 3 \mathrm{HT}$ solar cells using $\mathrm{CuPc}$ as a sensitizer. Appl. Phys. Lett., 92, pp.1-3.

5. Duofa, W., Haizheng, T., Xiujian, Z., Meiyan, J. and Tianjin, Z., 2015. Enhanced photovoltaic performance of $\mathrm{TiO}_{2} / \mathrm{P} 3 \mathrm{HT}$ hybrid solar cell by interface modification. J. Semiconductors, 36(2), p.023006(1-4).

6. Wu, J., Yue, G., Xiao, Y., Lin, J., Huang, M., Lan, Z., Tang, Q., Huang, Y., Fan, L., Yin, S. and Sato, T., 2013. An ultraviolet responsive hybrid solar cell based on titania/poly(3-hexylthiophene). Sci. Rep., 3, pp.1-6.

7. Xu, A-W., Gao, Y. and Liu, H-Q., 2002. The preparation, characterization and their photocatalytic activities of rare-earth doped $\mathrm{TiO}_{2}$ nanoparticles. J. Catalysis, 207(2), pp.151-157.

8. Akhavan, O., Abdolahad, M., Esfandiar, A. and Mohatashamifar, M., 2010. Photodegradation of graphene oxide sheets by $\mathrm{TiO}_{2}$ nanoparticles after a photocatalytic reduction. J. Phys. Chem. C., 114(30), pp.12955-12959.

9. Chen, J.S., Tan, Y.L., Li, C.M., Cheah, Y.L., Luan, D., Madhavi, S., Boey, F.Y.C., Archer, L.A. and Lou, X.W., 2010. Constructing hierarchical spheres from large ultrathin anatase $\mathrm{TiO}_{2}$ nanosheets with nearly $100 \%$ exposed (001) facets for fast reversible lithium storage. J. Am. Chem. Soc., 132(17), pp.6124-6130.

10. Meng, S., Ren, J. and Kaxiras, E., 2008. Natural dyes adsorbed on $\mathrm{TiO}_{2}$ nanowire for photovoltaic applications: Enhanced light absorption and ultrafast electron injection. Nano Lett., 8(10), pp.32663272 .

11. Shankar, K., Mor, G.K., Prakasam, H.E., Yoriya, S., Paulose, M., Varghese, O.K. and Grimes, C.A., 2007. Highly-ordered $\mathrm{TiO}_{2}$ nanotube arrays up to $220 \mu \mathrm{m}$ in length: Use in water photoelectrolysis and dye-sensitized solar cells. Nanotechnology, 18(6), p.065707(1-12)

12. Kang, S.H., Choi, S.H., Kang, M.S., Kim, H.S., Hyeon, T. and Sung, Y.E., 2008. Nanorod-based dye-sensitized solar cells with improved charge collection efficiency. Adv. Mater., 20(1), pp.54-58.

13. Mor, G.K., Shankar, K., Paulose, M., Varghese, O.K. and Grimes, C.A., 2006. Use of highly-ordered $\mathrm{TiO}_{2}$ nanotube arrays in dyesensitized solar cells. Nano. Lett., 6(2), pp.215-218; Cozzoli, P.D., Kornowski, A. and Weller, H., 2003. J. Am. Chem. Soc., 125, pp.14539-14548.

14. Dinh, C.-T., Nguyen, T.-D., Kleitz, F. and Do, T.-O., 2009. Shapecontrolled synthesis of highly crystalline titania nanocrystals. ACS Nano, 3(11), pp.3737-3743.

15. Frantz, C., Lauria, A., Manzano, C.V., Guerra-Nunez, C. Niederberger, M., Storrer, C., Michler, J. and Philippe, L., 2017. Nonaqueous sol-gel synthesis of anatase nanoparticles and their electrophoretic deposition in porous alumina. Langmuir, 33(43), pp.12404-12418.

16. Cargnello, M., Gordon, T.R. and Murray, C.B., 2014. Solution-phase synthesis of titanium dioxide nanoparticles and nanocrystals. Chem. Rev., 114(19), pp.9319-9345.

17. Li, Y., Zhang, M., Guo, M. and Wang, X., 2010. Hydrothermal growth of well-aligned $\mathrm{TiO}_{2}$ nanorod arrays: Dependence of morphology upon hydrothermal reaction conditions. Rare Metals, 29(3), pp.286-291.

18. Xiao, G., Shi, C., Li, L., Zhang, Z., Ma, C. and Lv, K., 2017. A 200$\mathrm{nm}$ length $\mathrm{TiO}_{2}$ nanorod array with a diameter of $13 \mathrm{~nm}$ and areal density of $1100 \mu \mathrm{m}^{-2}$ for efficient perovskite solar cells. Ceramics International, 43(15), pp.12534-12539.

19. Huang, Q., Zhou, G., Fang, L., Hu, L. and Wang, Z-S., 2011. $\mathrm{TiO}_{2}$ nanorod arrays grown from a mixed acid medium for efficient dyesensitized solar cells. Energy Environ. Sci., 4, pp.2145-2151.

20. Liu, B. and Aydil, E.S., 2009. Growth of oriented single-crystalline rutile $\mathrm{TiO}_{2}$ nanorods on transparent conducting substrates for dyesensitized solar cells. J. Am. Chem. Soc., 131(11), pp.3985-3990. 
21. Mali, S.S., Kim, H., Him, C.S., Patil, P.S., Kim, J.H., Hong, C.K., 2013. Surfactant free most probable $\mathrm{TiO}_{2}$ nanostructures via hydrothermal and its dye sensitized solar cell properties. Sci. Rep., 3(3004), pp.1-8.

22. Lin, J., Heo, Y-U., Nattestad, A., Sun, Z., Wang, L., Kim, J.H. and Dou, S.X., 2014. 3D hierarchical rutile $\mathrm{TiO}_{2}$ and metal-free organic sensitizer producing dye-sensitized solar cells $8.6 \%$ conversion efficiency. Sci. Rep., 4(5769), pp.1-8.

23. Kim, D.H., Seong, W.M., Park, I.J., Yoo, E-S., Shin, S.S., Kim, J.S., Jung, H.S., Lee, S. and Hong, K.S., 2013. Anatase $\mathrm{TiO}_{2}$ nanoroddecoration for highly efficient photoenergy conversion. Nanoscale, 5, pp.11725-11732.

24. Patil, P.B., Mali, S.S., Kondalkar, V.V., Pawar, N.B., Khot, K.V., Hong, C.K., Patil, P.P. and Bhosale, P.N., 2014. Single step hydrothermal synthesis of hierarchical $\mathrm{TiO}_{2}$ microflowers with radially assembled nanorods for enhanced photovoltaic performance. RSC Adv., 4, pp.47278-47286.

25. Yu, H., Pan, J., Bai, Y., Zong, X., Li, X. and Wang, L., 2013. Hydrothermal synthesis of a crystalline rutile $\mathrm{TiO}_{2}$ nanorod based network for efficient dye-sensitized solar cells. Chem. Eur. J., 27, pp.13569-13574.

26. Ye, M., Liu, H-Y., Lin, C., Lin, Z., 2013. Hierarchical rutile $\mathrm{TiO}_{2}$ flower cluster-based high efficiency dye-sensitized solar cells via direct hydrothermal growth on conducting substrates. Small, 9(2), pp.312-321.
27. Mali, S.S., Betty, C.A., Bhosale, P.N., Devan, R.S., Ma, Y.-R., Kolekar, S.S. and Patil, P.S., 2012. Hydrothermal synthesis of rutile $\mathrm{TiO}_{2}$ nanoflowers using bronsted acidic ionic liquid [BAIL]: Synthesis, characterization and growth mechanism. CrystEngComm., 14, pp.1920-1924.

28. Zhao, Y., Gu, X. and Qiang, Y., 2012. Influence of growth time and annealing on rutile $\mathrm{TiO}_{2}$ single-crystal nanorod arrays synthesized by hydrothermal method in dye-sensitized solar cells. Thin solid films, 520(7), pp.2814-2818.

29. Qin, D-D., Bi, Y-P., Feng, X-J., Wang, W., Barber, G.D., Wang, T., Song, Y-M., Lu, X-Q. and Mallouk, T.E., 2015. Hydrothermally growth and photoelectrochemistry of highly oriented, crystalline anatase $\mathrm{TiO}_{2}$ nanorods on transparent conducting electrodes. Chem. Mater., 27(12), pp.4180-4183.

30. Sui, M-R., Han, C-P., Gu, X-Q., Wang, Y., Tang, L. and Tang, H., 2016. Photoelectrochemical characteristics of $\mathrm{TiO}_{2}$ nanorod arrays grown on fluorine doped tin oxide substrates by the facile seeding layer assisted hydrothermal method. Opt. Lett., 12(3), pp.161-165.

31. Hong, S-P., Park, J., Bhat, S.S.M., Lee, T.H., Lee, S.A., Hong, K., Choi, M-J., Shokouhimehr, M. and Jang, H.W., 2018. Comprehensive study on the morphology control of $\mathrm{TiO}_{2}$ nanorods on foreign substrates by the hydrothermal method. Crystal Growth and Design, 18(11), pp.6504-6512.

Received: 29 October 2018. Accepted: 28 August 2019. 